\title{
A Study of the Relation between Market System Evolution and Enterprise Institution Change*
}

\author{
Xiang Gao \\ College of Economics \& Management, Henan Normal University, Xinxiang, China \\ Email: gx204@126.com
}

Received April 1, 2012; revised April 11, 2012; accepted May 18, 2012

\begin{abstract}
Market system experienced two stages: classical market system and modern market system. In the meantime, enterprise institution also achieved a great change from classical enterprise institution, company institution to modern company institution. In the evolution of market system and enterprise institution, they are restricted and promoted each other showing the relevance of interactive optimization.
\end{abstract}

Keywords: Market System; Enterprise Institution; Interactive Optimization

\section{Introduction}

Market system which takes exchange rules as the main body has experienced the evolution from classical market system to modern market system. The basic mark of classical market is free competition. The economic operation was regulated by a single market. However, in modern market system, market mechanism and plan mechanism jointly come to play. Enterprise institution change is the result of the development of productive forces and the deepening of social division. Enterprise institution has also experienced the evolution from classical enterprise institution, company institution to modern company institution. These stages are successional in time and coexisting in space. Market system and enterprise institution are in the process of continuous development and improvement in which they always interact with each other.

\section{The Impact of Market System Evolution on Enterprise Institution Change}

\subsection{The Formation and Improvement of Market System Provides the Basic Conditions for the Development and Expansion of Enterprise Organization}

In the early period of classical market system, market was small and market system was not perfect; capital market was at a developmental state; technology market was lacked; there were a few small transactions; the small size of business determined the widespread pres-

\footnotetext{
"This paper was supported by National Social Science Funds of China (Grant No. 11CJL026) and Talented Faculty Funds of Henan Normal university (Grant No. 05212).
}

ence of the classical enterprise institution. From classical market system to modern market system, capital market is gradually developed and achieves a relatively perfect degree; the scope of market are expanded from the region to the unified domestic market; international market system starts to be established and developed; so it is possible for enterprises to expand their scale. Meanwhile, the improvement of capital market makes sources of business capital become more social and meets the needs of enterprise expansion.

In addition to capital market, other factor markets also have an important impact on the development of enterprise organization.

- Technology market is essential for the development of new products.

- Information market is very important for the identification and implementation of business strategies.

- Labor market becomes a "reservoir" to absorb workers.

- Manager market provides manpower to ensure the separation of ownership, management and even control right. So the change of leaders of modern company doesn't affect the rise and fall of enterprise itself [1].

The separation of ownership and management power creates a professional class of entrepreneurs who put the new factor- "management" into the production and operation process of enterprises [2]. Division of labor is developed further because of the emergence of manager market. When entrepreneurs become professional operators, capitalists become professional investors. Since then, not factors, but enterprises become the object of owners 
of capital investment. Investment in enterprises is carried out in the capital market; therefore, the development of modern company institution necessarily creates a developed capital market which can provides not only sources of funds for large-scale enterprise investment, but also sources of venture capital for innovative enterprises [3].

Perfect market system requires effective competition which always is a basic characteristic of well-operated market. From classical market system to modern market system, market develops from sellers' market to buyers' market and the structure of market develops form free competition to the coexistence of free competition and monopolistic competition. The scope of market competition grows broader, and market gets more and more competitive, so bigger market risk is brought. In market economic activities, competition causes enterprises to be under an external strong pressure environment. The external pressure can be transformed into internal driving force in enterprises. It is necessary for enterprises to expand their scale, to reform their organization system and to perfect their internal organization structure.

\subsection{The Deepening of Market System Promotes Enterprise Property System Change Accordingly}

In the early period of classical market system, proprietorship individual or partnership enterprises adapt to the prevailing market segmentation and lack effective competition. With the deepening social division of labor and development of social productive forces, market is becoming increasingly larger and more competitive. When it is difficult for a single investment subject to undertake a major project, many investors will jointly invest. Thus, structural bottlenecks of the configuration of elements of social reproduction are overcome, and the efficiency of economy operation and resource allocation is improved. This joint behavior of multiple investors creates a new enterprise organization system-company system.

Development of the stock company is the most typical in all kinds of companies. A stock company is invested in by a number of investors, can raise a lot of money in the short term and can quickly accomplish the matter which a single investor achieves with difficulty. Therefore, it breaks restrictions of quantity and an area of individual capital, allocates assets in a broader region, and promotes further development of productive forces. As a new form of business organization, the company has a strong creative energy. Thus it soon is adopted extensively in the whole economic life.

In order to adapt to the development of productive forces, enterprise organization system has undergone changes in property, from centralized investment to diversified investments. As a company is regarded by the law as a person-an artificial person corresponding with natural person, enterprises who make use of capital obtain independent legal personality. The separation and independent of ownership and corporate property rights are achieved [4].

The evolution of market system not only can optimize and regulate mechanisms, but also can select and optimize enterprise organization system. The evolution of market system requires the development of enterprise institution to fit it. Pattern of ownership which is formed by different enterprise property systems is the basis for different types of market system. On the contrary, it certainly makes against and even hinders the survivals and development of the enterprises that enterprises take the organization system which gets behind or ahead of market. Both classical enterprise institution in classical market system and modern company institution in modern market system are enterprise institutions that adapt to the prevailing market system. Moreover, along with the development of market, enterprise institution also changes correspondingly in synchronization with the evolution of market. In addition, the evolution of market also optimizes the internal organization system of enterprises so that it can adapt to the development of market.

\subsection{In the Development of Market System, Enterprises Are Required to Make Up for the Role of Market}

Market failure indicates that market is not a panacea. Market mechanism has its inherent flaw that is the cost of using price mechanism. Using price mechanism not only requires a series of contracts are achieved between the different elements, but also requires the short-term contracts are achieved for the same repetitive transactions, which led to high costs of market transactions. But by forming an organization and allowing some authority (an "entrepreneur") to direct the resources, certain marketing costs are saved [5]. In an enterprise, a long-term contract is made for the supplies of goods and services, which not only saves the costs of repeated negotiations and signing contracts, but also overcomes the difficulty of predicting the future. Therefore, the development of market institutions requires necessarily that enterprise organizations make up for the role of market. From classical market system to modern market system, an enterprise expands its scale step by step and gradually puts some market transactions into the internal of the organization. Market failure is overcome in a way.

Enterprise organization can make up for market failure. However, market can also supersede enterprise in certain conditions. In large modern companies, the structure is so complex and the scale is so large that highly centralized planning mechanisms are formed, which results in 
the failure of organizational function. When the scale of company is constantly expanded to more than the maximum effective size, operation costs will be raised, which we call "scale diseconomies". Therefore, a large enterprise must find an effective form of organization and make choice and trade-off between size and effectiveness. The optimal scale of enterprise is shown in Figure 1. Market supersedes enterprises by two modes-externalization and internal market. It is externalization that transactions are carried out in market instead of enterprises themselves. When costs of transactions in an enterprise are too high, or the transactions are unimportant to an enterprise, or when an enterprise is in trouble, without possibility of growth, externalization may occur. It is internal market that market mechanism is introduced to the inner of enterprises which make enterprises generate rapid and continuous changes in the structure as similar as market.

\section{The Impact of Enterprise Institution Change on Market System Evolution}

\subsection{Enterprise Institution Change Not Only Restricts or Promotes the Play of Market Mechanism and Function in a Way, but Also Lays the Microscopic Basis for the Conversion of Market Economy from Classical System to Modern System}

The changes of property organization system of enterprises that are the main body of market have an important impact on the play of market mechanism and function market. In the early period of classical market system, enterprise scale was small and there was only a single consumer goods market. With the development of productive forces, enterprises require capital goods to be put into circulation process. A single capital goods market is already unable to meet the needs of expanding enterprise organization. The scale of enterprises grows larger and larger to gradually exceed the limitation of individual

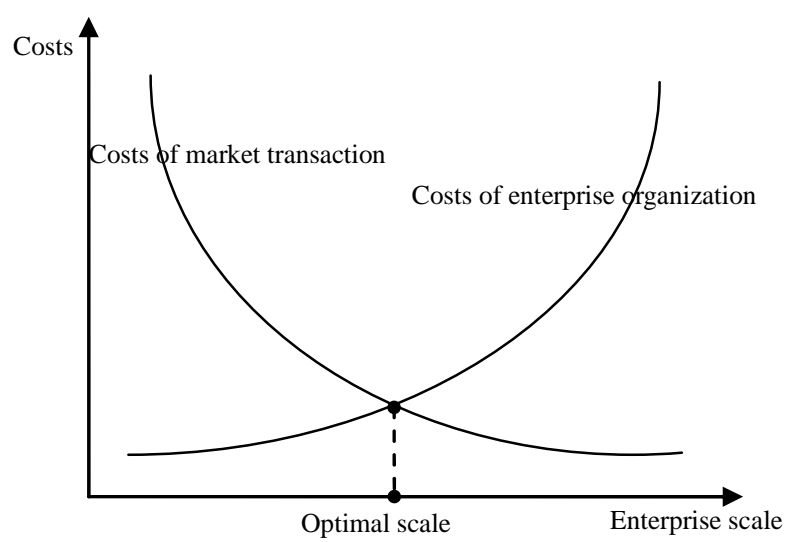

Figure 1. The optimal sclale of enterprises. capital. Then, the socialization of capital is needed, which requires a more complete capital market to provide assurance.

With the increasing scale of business, the degree of complexity and socialist of the production becomes higher and higher. The original enterprise institutions that investors also are managers can not adapt to the new situation. A manager with management knowledge and experience is required to occupy a main place of the enterprise. The perfect manager market is required to provide sources and flow of talents for the engenderer of "managerial revolution" [6].

In addition, the changes of property organization system of enterprises also promote the development and improvement of technology market, real estate market, information market, property rights transaction market, and labor market.

The emergence and development of modern company contribute to the formation of modern market system. In modern market system, the scale of enterprises has the trend of continuous expansion. The frequent combination and vertical integration of enterprises promote the development of capital markets, and provide an effective way for the reasonable flowing of production factors. As a kind of economic organizations that pursuit the maximization of interests, enterprises promote the expansion of the scope of market. The expansion of enterprise requires that the region segmentation of market should be broken; the expansion of production scale is conducive to the application of large-scale production technology that will accelerate the expansion of enterprise in turn, which surely break the barriers between markets and promote the formation of a unified domestic market. Moreover, in order to pursue profit, enterprises which are unwilling to be limited in existing market conditions will explore international market. Large enterprise groups and multinational companies always conduct business in international market. So the formation of international market and the establishment and perfect of international market system are promoted.

\subsection{Enterprises Can Partly Supersede and Control Market}

Coase considered the capitalist enterprise as an organization, which is different from microeconomic body in the pre-capitalist period. The operation of organizations and market mechanism all have cost. As executive orders play the key role in organizations, the costs of organizations are usually less than transaction costs of market in which buyer bargains with seller for goods. Therefore, the distinguishing mark of the firm is the supersession of the price mechanism, in other words, enterprises and market may be regarded as two kinds of modes of re- 
source allocation which can be substituted mutually. Because of uncertainty and market failure, if market transaction costs are difficult to be measured or too high, enterprises may carry out the transaction in the organization, purposely configure and co-ordinate resources through the management power in order to reduce transaction costs. That is to say, when the coordination of management can bring greater productivity, lower costs and higher profits than the coordination of market system, enterprises will set up new departments that deal with business which is previously conducted in market. To a certain extent enterprises begin to supersede market.

Large enterprises can dominate market in a way. Under market conditions of imperfect competition, a competitive strategy of a large enterprise will make an impact, or even a significant impact on market, buyers, suppliers, competitors. As the scale of modern company is constantly expanded, the influence and control on market grow stronger day by day. "Corporate economy" is formed. In the economy, the scale of enterprises is so large that they can control social economy and political affairs. For these large enterprises, price does not play a very important role on how to allocate resources. Depending on the long-term contracts of prices and numbers of goods and services, large enterprise can minimize the impact of market uncertainty. These enterprises are no longer restricted by market information. They overtop market and regard it as a tool for them [7].

\section{Conclusion}

Market system evolution is directly associated with enterprise institution change. In the evolution of market system and enterprise institution, they are restricted and promoted each other showing the relevance of an interactive optimization. Market system is deepened constantly from classical market system to modern market system. Accordingly, enterprise institution also achieved a great change from classical enterprise institution, company institution to modern company institution. The evolution of market system not only promotes the development of enterprise organization and the expansion of enterprise scale, but also requires the enterprise property system to be changed and the form of enterprise organizations to be selected and optimized. In particular, it requires enterprise organizations to make up for the role of market. Moreover, market can also supersede enterprise in certain conditions. Similarly, the change of enterprise institution also promotes the evolution of market system and affects the play of market mechanism and function. Enterprises have substitution effect on market, even can overtop and control market.

\section{Acknowledgements}

Thanks to professor He Lisheng, who gave me some professional suggestions on revision. Thanks to associate professor Yue Dongli, who helped me modify words and grammar errors in English.

\section{REFERENCES}

[1] Y. B. Ma and R. Q. Chen, "From Two Rights Separation to Three Rights Separation: The Solution on PrincipalAgent Problems in Companies," Science \& Technology Progress and Policy, Vol. 20, No. 2, 2003, pp. 44-46.

[2] M. Hua, "Capitalistic Dynamic Fore, Institutional Innovation and It's Crisis,” Fudan Journal (Social Sciences), No. 6, 2000, pp. 1-10.

[3] F. C. Wu, "Nature of the Enterprise and Market," Nankai Economic Studies, No. 6, 2001, pp. 26-301.

[4] C. P. Cheng and J. T. Duan, "On the Differences between Enterprise and Market,” Finance \& Economics, No. 3, 2004, pp. 45-49.

[5] R. H. Coase, "The Nature of the Firm," Economica (New Series), Vol. 4, No. 16, 1937, pp. 386-405.

[6] A. D. Chandler Jr., "The Visible Hand-The Managerial Revolution in American Business,” Belknap Press, Cambridge, 1977.

[7] Y. S. Mao, "On the Relationship between the Enterprise and the Market," Journal of Yatsen University (Social Science Edition), No. 6, 1999, pp. 91-95. 